\title{
Teleki AnNA \\ Elvesztett jelentés, avagy ahol a fordító kompetenciája véget ér
}

A fordítóra munkája során számos várt és váratlan nehézség, megoldásra váró probléma leselkedik, melyek elsősorban grammatikai szinten mutatkoznak meg, hiszen az orosz szövegben találkozhat olyan szavakkal, szókapcsolatokkal, amelyek nem adhatók vissza adekvátan a célnyelvben, és így a fordítási folyamatban jelentésvesztés történik. Elöfordulhatnak egyedi esetek, ahol mindez azért megy végbe, mert az orosz szónak nincs magyar megfelelője - erre az egyik leggyakrabban emlegetett példa talán a соборность szó lehet.

Lexikális szinten további problémát okozhat az is, ha a szöveg egésze tájnyelvi szavakkal, egy adott etnikai közösség saját, esetenként több nyelvből vagy egy nyelv különböző nyelvváltozataiból létrehozott szókincsével, kulturális- és szubkulturális, vallási csoportok egyedi zsargon szókészletével annyira telített, hogy a mü más nyelvekre egyszerüen lefordíthatatlanná válik. Erre igazán szemléletes példa Mihail Gigolasvili Tolmács címü regénye, amelyről maga a szerző nyilatkozta: nem hinné, hogy le lehetne fordítani más nyelvekre, mivel „a szereplők szövegében túl sok nyelvi játék van, kevert nyelv, barbarizmus, argó, zsargon, dialektusok (beleértve a szurzsikot és a traszjankát is) stb., amelyekből aligha lehet adekvát fordítást készíteni, ezek nélkül viszont a regény elveszíti a kvalitását”. ${ }^{1}$

A jelen dolgozat problémafelvetése a már említett grammatikai-lexikális szinten túllépve abból a fordításelméleti tényből indul ki, hogy a fordítás - kultúrák fordítása, vagyis kulturális transzfer. A fordítónak a nyelvi kompetencia mellett birtokában kell lennie mind a saját, mind annak a népnek a kultúráját érintő átfogó ismeretanyaggal, amelynek nyelvéből fordít. Fontos kiemelni, hogy nemcsak a szépirodalmi utalásokat kell felismerni a szövegben, hanem tisztában kell lenni a reáliákkal, kulturális jelenségekkel, szokásokkal is, a kortárs müvek esetében pedig kimondottan hangsúlyos a mai Oroszország, a mai orosz beszélt nyelv, az újhullámos kultúra, filmek, zenék és esetenként még a médiajelenségek ismerete is. Szintén fordításelméleti tény, hogy olyan megoldásokra van szükség a fordítási problémák feloldása során, amelyekben a forrásnyelvhez tartozó kulturális jelenségek a célnyelvben meglévő kulturális jelenségekre cserélendők. A folyamat során, szem előtt tartva azt, hogy a szöveg-fordítóolvasó hármasában az olvasón van a hangsúly, arra kell törekedni, hogy az olvasó a

\footnotetext{
${ }^{1}$ Mihail Gigolasvili, Ogyinocsesztvo - molcsanyije - muzika = Kak mi pisem, eds. P. Kruszanov, A. Jetojev, Szankt-Petyerburg, Azbuka, 2018, 150. (Amennyiben külön nem jelzem a fordítót, akkor az idegen nyelvü idézeteket a saját fordításomban közlöm. - T. A.)
} 
lehető legtöbbet kapja vissza az eredeti jelentésből, úgy, hogy az utalásokból, mögöttes tartalmakból a lehető legkevesebb vesszen el.

A kortárs orosz irodalom egyik kiemelkedő szerzőjét, Roman Szencsint - aki témáival és elbeszélői módszerével a 2000-es évek elején indult „új realista” irányzathoz kapcsolódik - gyakran éri támadás a kritika és az olvasók részéről, hogy nem tesz mást, mint egyszerüen leírja a körülötte zajló történéseket. Szencsin szépírói jelentősége azonban éppen abban rejlik, hogy a mai orosz valóságra jellemző társadalmi és kulturális miliőt, tipizált karaktereket, szubkulturális jelenségeket örökíti meg. Saját szerzői gyakorlatáról $A z$ élet írja címü önéletrajzi esszéjében úgy vall, hogy próbált ugyan olyan korokról írni, amelyekben sohasem élt, ezek a próbálkozásai azonban legtöbbször kudarcba fulladtak. Számára mindig az őt körülvevő világ bizonyult a legizgalmasabbnak, ezért nyíltan vállalja, hogy műveinek túlnyomó többsége a jelen világ eseményeiből merít, szüzséi gyakran önéletrajzi ihletésűek, sőt, elbeszélöi gyakran önmaga alteregóiként értelmezhetők.

Szencsin $A z$ igazi férfi (Настоящий парень) címü novellája egy végleg letünni látszó orosz nemzeti típusnak állít emléket, úgy, hogy a szöveg középpontjába hangsúlyos intertextuális elemként $A$ fivér (Брат) ${ }^{3}$ címü orosz kultuszfilmet - egészen pontosan a film kulturális lenyomatát - helyezi, továbbá megjeleníti három irodalmi mü reminiszcenciáját is, hogy megmutassa és alátámassza különböző korok höseinek, vagy éppen antihőseinek karakterjegyeit. A jelen dolgozatnak nem célja öszszehasonlító elemzésben kapcsolódási pontokat keresni egyik vagy másik intertextus és a novella között, mindösszesen arra vállalkozik, hogy néhány példa segítségével bemutassa, milyen nehézségekbe ütközik a fordító, amikor kísérletet tesz az orosz eredeti szövegben megjelenő többletjelentések, utalások átörökítésére a magyar szövegbe, és ezekből az árnyalt jelentésekből, amelyek az orosz kulturális emlékezet részét képzik, mennyi vész el a magyar olvasó számára.

$A z$ igazi férfi címü novella felidézi azt a kedvelt narrációs eljárást, amelynek során a szerző-elbeszélő az örökkévalóságnak tűnő vonatútjai alkalmával megfigyeli utastársait, hogy műveihez megfelelő karaktereket találjon. A transz-szibériai vonaton ülve olyan arcokat keres, akikben még megvan a tiszta elevenség, a belső erő és a természetes jóság, akik ösztönösen tisztességesek és becsületesek, akik megértettek valami fontosat az őket körülvevő világból. A szerző-elbeszélő nosztalgikus-elégikus hangon mesél egy olyan nemzeti karakter eltűnéséről, feloldódásáról a kortárs orosz társadalomban, amelynek ábrázolásához megidézi $A$ fivér című filmet és kultikus főszereplőjét, Szergej Bodrovot, hiszen ezt a nemzeti karaktert nemcsak az orosz vidék egyszerű embereiben látta, hanem a színész által megformált Danyilában és nemzedékében is. A fivér 1997-es bemutatása után óriási sikert aratott, és az új nemzedék kultuszfilmjévé vált. Bodrovot rajongói gyakorlatilag azonosították filmbéli

${ }^{2}$ Roman Szencsin, Pisu po hodu zsiznyi = Kak mi pisem, i. m., 488-509.

${ }^{3}$ A fivér (Брат) (1997), rendezte Alekszej Balabanov. (A filmet Magyarországon is bemutatták.) 
karakterével, a csecsen háborúból hazatért egyszerü vidéki fiúval, Danyila Bagrovval, aki a jobb élet reményében utazik Szentpétervárra. Danyila bátyja már régóta a nagyvárosban él, és hamar kiderül, hogy közel sem tisztességes munkával keresi a kenyerét: bérgyilkosként „dolgozik”, és kész átadni a megbízásait az öccsének, persze úgy, hogy a haszon nagyobbik fele a saját zsebében maradjon. A csecsen harcokban kiváló katonai ismeretekre szert tett fiú hidegvérrel elvégzi a rábízott feladatot: ha kell, gyilkoló géppé változik. Danyila karakterének lényege, a benne lakozó, a vidékről hozott elemi őserő azonban nem ebben rejlik. Pétervár utcáin önjelölt igazságosztóvá, ha úgy tetszik, modernkori Robin Hooddá válik: a szegények és elesettek védelmére kel, és könyörtelenül megleckézteti a rosszfiúkat.

Szergej Lavrentyev azt írja a film kapcsán, hogy a nézők és a kritika már régóta várt olyan karakterre a mozivásznon, aki nemzedékének és korának tökéletes megtestesítője. Korunk titokzatos hösének típusa Bodrov - fogalmaz Aljona Szolnceva -, aki valójában nem képzett színész, nemcsak egyszerüen eljátssza, hanem életre is kelti szerepét a mozivásznon. Belülről fakadó ösztönös eröre van szükség Danyila Bagrov megformálásához, és ez megvan Bodrovban. ${ }^{4}$ Szencsin pontosan ennek a nemzeti típusnak kiveszését látja később az ezredforduló utáni nemzedékben. Az általa tapasztalt jelenség hátterében ok-okozati összefüggésként bontakozik ki az erős orosz vidék és a gyenge város szembenállásának problémaköre, melynek még árnyaltabb megjelenítésére, mintegy megerősítésként emeli be a szövegbe A fivért. Szinte szó szerint idéz a filmből, amikor arról beszél, hogy „Сама жизнь делает человека слабым. [...] кто появляется сильный, быстро размякает. Я тоже отсюда, из Сибири, в Москву сильным приехал.” („Az élet teszi gyengévé az embert. [...] ha valaki erősnek bizonyult, az gyorsan meggyengült. Én is idevalósi vagyok, szibériai, és Moszkvába erősen érkeztem.”) Hasonló gondolatok hangzanak el A fivér végén: „Вот ты говорил, город - сила, а здесь слабые все. - Город, это злая сила. Сильный приезжает, становится слабым. Город забирает силу.” („Azt mondtad, a város - erő, de itt mindenki gyenge. - A város gonosz erő. Erősen érkezel, de itt meggyengülsz. A város elveszi az erőt.")

Ehhez kapcsolódva, annak alátámasztására, hogy mennyire domináns A fivér jelenléte Szencsin szövegében, érdemes még egy szemléletes példát kiemelni: a film betétdala, a legendás orosz Nautilus zenekar Крылья (Szárnyak) címü száma, ha úgy tetszik, megszólal a novellában is: kiszürődik a tinédzser lány fülhallgatójából és így végig hallatszik a vonaton is, amikor az elbeszélő Bodrov nemzedékéről beszél. A Szárnyak refrénje - „Мы все потеряли что-то, на этой безумной войне. Кстати, где твои крылья, которые нравились мне?”6 („Mindannyian elvesztettünk valamit

\footnotetext{
${ }^{4}$ A két szerző kritikájából vett citátumok itt olvashatók: 20 let Bratu: sto piszali krityiki o filme v 90-e. https://daily.afisha.ru/cinema/5893-chto-pisali-o-brate/ (Letöltés ideje: 2020. február 21.)

${ }^{5}$ Idézet a szövegből itt, és a továbbiakban: Roman Szencsin, Nasztojascsij pareny = R. Sz., Szriv, Moszkva, Izdatyelsztvo ASZT, 2016, 306-307.

${ }^{6}$ Idézet a Nautilus nevü orosz zenekar Krilja címü számából. https://www.gl5.ru/nautilus-pompiliuskrylya.html (Letöltés ideje: 2020. február 21.)
} 
ebben az örült háborúban. Tényleg, hol van a szárnyad, amely úgy tetszett nekem?") - még világosabbá teszi nemcsak a film, hanem Szencsin elbeszélésének mondanivalóját is: egy orosz nemzeti karakter, az ösztönös őserőt képviselő egyszerü vidéki srác tünik el, mert a város gyengévé teszi.

A novella címét adó szókapcsolat, а настоящий парень, amely igazi, valódi fiatal srácot jelent, és többször is megjelenik a szövegben - például amikor a szerző Bodrovról és nemzedékéről beszélget az utastársával, majd pedig a szöveg végén, amikor visszaemlékezik erre a nemzedékre -, azokra a 90-es évekbeli fiatalokra vonatkozik, akikben még volt valami spiritusz, valami ösztönös érzék az élethez. A szókapcsolatnak, vagy csak önmagában а настоящий szónak jelentése tehát, függetlenül attól, hogy az adott szöveghelyen és az adott kontextusban éppen kire vagy mire vonatkozik, a mögöttes tartalom miatt mindig magában foglalja $A$ fivér kultuszát, vagyis Bodrov korszakának és nemzedékének hős-típusát, és a rendszerváltás utáni orosz mindennapok ködös, borús ízét. A fordításnál tehát figyelembe kell venni azt, hogy a szókapcsolat minden esetben ennek a nemzeti karakternek a definíciója lesz.

A szövegben több helyen jobb megoldásnak bizonyult volna a настоящий-t valódinak fordítani (például: „Нету там настоящего.” - „Ott nincs semmi valódi.”; „не в этом их настоящесть...” - „valódiságuk nem ebben rejlett...”), és а настоящий парень „valódi srác”-nak fordítása is jobban kifejezte volna a szöveg mondanivalóját, hiszen sokkal inkább fiatal srácokról van szó, mintsem férfiakról. Azoknál a szöveghelyeknél viszont, ahol а настоящий парень szókapcsolat szerepelt, stilisztikailag jobban megfelelt az „igazi férfi” fordítás (például: „Он настоящий парень!” - „Ö egy igazi férfi!”, bár tartalmilag az „Ö egy valódi srác” jobban beleillene a szövegbe). A novella tartalmi vonatkozásait figyelembe véve fontos hangsúlyozni, hogy a szöveg egészében a настоящий-nak mindig а сильный lesz a szinonimája, а слабый pedig az antonímája, függetlenül attól - ha kizárólag a lexikai jelentésre korlátozódnánk -, hogy a magyar nyelvben magától értetődően az igazi antonímája nem a gyenge lenne, hanem sokkal inkább a hamis.

Azon túl viszont, hogy a novella tartalmi része a film mint intertextus mondanivalójára helyezi a hangsúlyt, amely nemcsak idézetekben és utalásokban kerül a felszínre, hanem, ha úgy tetszik, materializálódik (például amikor a vonatra felszálló tinédzser lány kiragasztja Bodrov fényképét a fülke falára, vagy amikor a fülhallgatójából kiszűrődik a film betétdala), azt is szem előtt kell tartani, hogy az értelmezési horizonton még két másik mủ is megjelenik. A címmel és azzal, hogy a szöveg középpontjába a nemzeti hős karaktertípust helyezi, Szencsin beemel a szövegbe két szépirodalmi müvet, két különböző irodalmi irányzatból és korszakból. Az egyik közülük, Borisz Polevoj Egy igaz ember ${ }^{7}$ (Повесть о настоящем человеке) а szocialista realizmus jegyében született, és így a szocialista diskurzushoz erősen kapcsolódó - egyébként valós eseményeken alapuló - műve. A szüzsé szerint Mereszjev, a

${ }^{7}$ Borisz Polevoj, Egy igaz ember, ford. Madarász Emil, Bp., Európa, 1978. 
Vörös Hadsereg pilótája, miután gépével lezuhan, és a baleset következtében súlyos lábsérülést szenved, a hóban csúszva-mászva addig küzd, amíg vissza nem tér az övéihez. Elüszkösödött lábát amputálják, ám a szovjet hős nem adja fel a hazájáért és népéért folytatott harcot, és protézis segítségével újra gépre száll. A másik megidézett mü Olga Szlavnyikova $A$ halhatatlan: elbeszélés egy valódi emberröl ${ }^{8}$ (Бессмертный - Повесть о настоящем человеке) címü, 2001-ben megjelent regénye, amely nyílt utalás Polevoj elbeszélésére, és egy hadirokkant veteránt gondozó család groteszk mindennapjain keresztül ábrázolja a Brezsnyev-korszak végének következtében egyre inkább a kapitalizmus felé tartó orosz valóságot. Ez a valóság azonban a cselekmény elörehaladtával egyre inkább elválik a veterán világától, ugyanis a rokonai illúzióba kényszerítik azzal, hogy eltitkolják előle az országban végbemenő politikai és gazdasági változásokat. ${ }^{9}$

Figyelembe véve a megidézett két szépirodalmi müvet és a már bővebben tárgyalt film tartalmi vonatkozásait, világossá válik, hogy Szencsin mint kulturális konnotációt helyezi őket novellája hátterébe, és ezáltal egy kultúrtörténeti paradigmán megy végig, hogy bemutassa, mikor, melyik kornak mit jelentett, vagy éppen mit nem jelentett az igazi hős. Nem ad végérvényesen létjogosultságot sem egyik, sem másik típusnak sem, hiszen azt, hogy számára - vagyis inkább a szerző-elbeszéló számára - Bodrov nemzedékének fiataljai jelentették az igazi alakokat, melyekhez hasonlókkal azóta sem találkozott, csak az elbeszélés záró akkordjában, elégikus, önreflexív vallomásban, retrospektív nézőpontból nyilatkoztatja ki. A történet közepén, amikor felvetödik az igazi férfi problémaköre, még nagyon is ironikus felhanggal viszonyul $A$ fivér kultuszához és képviselőihez, és értékelésében egyértelmü utalást tesz Lermontov Korunk hösére is. ${ }^{10}$

Szembesülve azzal, hogy milyen gazdag és szerteágazó kulturális háttéranyaggal dolgozik Szencsin $A z$ igazi férfi címü novellájában, joggal érezhetünk hiátust az általam fordított magyar szövegben, ${ }^{11}$ ugyanis azok az árnyalt utalások, finom motívumok, amelyek az orosz olvasó számára világosan felismerhetők és nyomon követhetők, a magyar olvasó számára - legyen bármilyen pontos is a fordítás - rejtve maradnak, mivel a magyar olvasó nem rendelkezik azokkal az orosz kultúraspecifikus ismeretanyagokkal, amelyek az orosz kulturális tudat részét képezik.

\footnotetext{
${ }^{8}$ Olga Szlavnyikova, A halhatatlan: elbeszélés egy valódi emberröl, ford. Goretity József, Bp., Noran, 2008.

${ }^{9}$ Szlavnyikova regényéről lásd bővebben Szőke Katalin, Mit akar(hat) az orosz nő, Tiszatáj, 2013/8, 79-87.

10 „Вот он, герой поколения. Двух слов не может связать. Уверенный, силный. Жалько, что в жизни таких что-то нет.” - „Itt van ő, nemzedéke hőse. Két értelmes szót sem bír kinyögni. Magabiztos, erös. Kár, hogy az életben nincsenek ilyenek."

${ }^{11}$ Roman Szencsin, Az igazi férfi, ford. Teleki Anna = Kettös tükörben, szerk. Goretity József, Okszana JAKIMENKo, Bp., Kairosz, 2019, 175-183.
} 


\title{
Teleki Anna \\ PhD-hallgató \\ Debreceni Egyetem \\ annacska.teleki@gmail.com
}

\section{Lost Meaning, or Where the Translator's Competence Ends}

\begin{abstract}
The paper analyses a short story from one of the best known representatives of the Russian new realist literature, Roman Senchin's "A Real Man" ("Nasztojascsij pareny"), and it also examines the experiences of the Hungarian translator in connection with its translation. The article focuses on the loss of meaning which is generated by the differences between the two distinct cultures, despite the best efforts of the translator. The Senchin text poses a near impossible task for the translator because of its intertextual connections with the Russian cult film, Brother, together with the untranslatable cultural codes in the film.
\end{abstract}

Keywords: Roman Senchin, “new realism”, difficulties of translation, intertextuality

DOI: 10.37415/studia/2020/1-2/55-60.

Open Access: Creative Commons Attribution 4.0 International (CC BY 4.0) (c) (i) 